\title{
Formulasi Minuman Bubuk Berbahan Dasar Beras Hitam (Oryza sativa L. indica) untuk Lansia Penyandang Diabetes Mellitus Tipe 2
}

\author{
Formulation of Black Rice (Oryza sativa L. indica) Powdered Beverage for Elderly with Type 2 Diabetes \\ Mellitus \\ Rianita Pramitasari ${ }^{1 *}$, Mary Astuti ${ }^{2}$, Yustinus Marsono² \\ ${ }^{1}$ Program Studi Teknologi Pangan, Fakultas Teknobiologi, Universitas Katolik Indonesia Atma Jaya, Jl. Jenderal \\ Sudirman No. 51, Jakarta 12930, Indonesia \\ 2Departemen Teknologi Pangan dan Hasil Pertanian, Fakultas Teknologi Pertanian, Universitas Gadjah Mada, J. \\ Flora, Bulaksumur, Yogyakarta 55281, Indonesia \\ *Email: rianita.pramitasari@atmajaya.ac.id
}

Submisi: 15 Juli 2016; Penerimaan: 24 November 2017

\begin{abstract}
ABSTRAK
Penelitian ini bertujuan untuk mendapatkan formula minuman bubuk berbahan dasar beras hitam untuk lansia penyandang diabetes mellitus (DM) tipe 2. Formulasi minuman bubuk dilakukan dengan mencampur bubuk nasi beras hitam dengan ekstrak protein kedelai hitam, ekstrak antosianin beras hitam, aspartam, dan garam dapur berdasarkan perhitungan energi total, cita rasa, dan kadar antosianin total. Analisis meliputi komposisi kimia (kadar air, abu, protein total, lemak total, dan karbohidrat) bubuk nasi beras hitam, ekstrak protein kedelai hitam dan kadar antosianin total. Pada minuman bubuk hasil formulasi dihitung komposisi nilai gizi, uji kesukaan, aktivitas antioksidan, dan Angka Kecukupan Gizi (AKG). Hasil penelitian menunjukkan bahwa satu takaran saji dengan berat $19,91 \mathrm{~g} / 200 \mathrm{~mL}$ mengandung antosianin $100 \mathrm{mg} /$ takaran saji, karbohidrat 10,34 g, protein 5,91 g, dan lemak 0,77 g. Minuman yang dihasilkan memiliki tingkat kesukaan sebesar 4,8 (netral-agak menyukai) berdasarkan uji sensoris pada lansia, memiliki aktivitas antioksidan $93,33 \pm 0,95 \%$ berdasarkan kemampuan penangkapan radikal DPPH, dan mampu mencukupi 3,68-4,52\% kebutuhan energi total/takaran saji berdasarkan AKG lansia per hari.
\end{abstract}

Kata kunci: Beras hitam; lansia; formulasi; minuman bubuk; diabetes mellitus tipe 2

\begin{abstract}
The aim of this research was to get a formula of black rice powder beverage for elderly with type 2 diabetes mellitus. The formulation was done by mixing gelatinized black rice powder with black soybean protein extract, black rice anthocyanin extract, aspartame, and salt based on total energy calculation, taste, and anthocyanin content. The analysis included chemical composition (moisture, ash, total protein, total lipid, and carbohydrate content) of gelatinized black rice, black soybean protein extract, and total anthocyanin content. Nutritional composition, sensory, antioxidant, and recommended dietary allowance of beverage powder was examined. The result showed that each serving with weight $19.91 \mathrm{~g} / 200 \mathrm{~mL}$ contained $100 \mathrm{mg}$ of anthocyanin, $10.34 \mathrm{~g}$ of carbohydrate, $5.91 \mathrm{~g}$ of protein, and $0.77 \mathrm{~g}$ of fat. The beverage had 4.8 (neutral-rather like) of preference level based on sensory analysis in elderly. The antioxidant activity based on DPPH radical scavenging ability was $93.33 \pm 0.95 \%$ of and could suffice $3.6-4.52 \%$ of total energy/serving based on recommended dietary allowance.
\end{abstract}

Keywords: Black rice; elderly; formulation; powdered beverage; type 2 diabetes mellitus

\section{PENDAHULUAN}

Lansia membutuhkan perhatian yang sangat serius karena mengalami perubahan dan kemunduran fisik maupun fisiologis akibat penuaan (Navaratnarajah dan Jackson, 2013). Penuaan pada lansia menyebabkan peningkatan kondisi stres oksidatif (Kumawat dkk.,
2012) yang memicu penyakit degeneratif seperti DM tipe 2. Berdasarkan hasil Riset Kesehatan Dasar, prevalensi DM tipe 2 di Indonesia pada kelompok lansia paling tinggi jika dibandingkan dengan kelompok usia lain. Pada tahun 2007, prevalensi DM pada lansia di Indonesia sebesar $14 \%$, kemudian mengalami peningkatan menjadi 25,6\% pada tahun 2013 . 
Lansia penyandang DM tipe 2 membutuhkan asupan energi dan antioksidan untuk menjaga kesehatan dan melindungi lansia dari kondisi stres oksidatif. Antosianin merupakan salah satu antioksidan yang memiliki kemampuan dalam menangkal radikal bebas penyebab stres oksidatif (Hou dkk., 2013a). Salah satu bahan pangan yang mengandung antosianin ialah beras hitam (Chen dkk., 2012). Beras mengandung karbohidrat, protein, dan lemak yang dapat digunakan sebagai sumber energi. Antosianin dari beras hitam dilaporkan mampu memperbaiki kondisi DM dengan cara meningkatkan sensitivitas insulin yang ditandai dengan penurunan indeks homeostatic model assessment insulin resistance (HOMA-IR) dan menurunkan penanda tingkat stres oksidatif (malondialdehid dan glutation teroksidasi) pada tikus Sprague Dawley yang diberi pakan tinggi fruktosa (Guo dkk., 2007).

Konsumsi beras hitam pada lansia penyandang DM tipe 2 akan mengalami hambatan akibat berkurangnya gigi dan kemunduran fungsi fisiologis dalam sistem pencernaan. Pramitasari dkk., (2013) telah melakukan penelitian pengembangan produk minuman berbasis beras hitam dalam bentuk bubuk yang mudah dikonsumsi lansia. Akan tetapi, aktivitas antioksidan dan kadar protein pada minuman tersebut masih rendah, serta mengandung sukrosa yang cukup tinggi sehingga tidak baik untuk lansia penyandang DM tipe 2. Oleh sebab itu, dalam penelitian ini dilakukan perbaikan formula dengan penambahan ekstrak antosianin beras hitam dan ekstrak protein kedelai hitam. Kedelai hitam dilaporkan mampu menurunkan kadar glukosa darah dan meningkatkan sensitivitas insulin pada tikus diabetes (Jang dkk., 2010). Selain itu, digunakan aspartam sebagai pengganti sukrosa untuk meningkatkan cita rasa tanpa menyebabkan kenaikan kadar glukosa darah.

Penelitian ini bertujuan untuk mendapatkan formula minuman bubuk berbahan dasar beras hitam yang dapat digunakan untuk melengkapi kebutuhan gizi lansia dan mempunyai sifat sensoris yang disukai, serta mengetahui aktivitas antioksidan pada minuman bubuk.

\section{METODE PENELITIAN}

\section{Bahan}

Bahan utama yang digunakan dalam penelitian ini adalah beras hitam varietas Wulung dalam bentuk beras pecah kulit yang diperoleh dari petani di Sawangan, Magelang, Jawa Tengah; kedelai hitam varietas Malika diperoleh dari Pacitan, Jawa Timur; dan ekstrak antosianin beras hitam dalam bentuk bubuk diperoleh dari Shaanxi Zhengseng Kangyuan Bio-medical Co., Ltd., China. Sebelum digunakan, beras dan kedelai disimpan di ruang pendingin pada suhu $4^{\circ} \mathrm{C}$, sedangkan ekstrak antosianin beras hitam disimpan dalam ruang pendingin suhu $-20{ }^{\circ} \mathrm{C}$ untuk menghindari perubahan komposisi kimianya. Bahan tambahan yang digunakan untuk formulasi adalah pemanis aspartam dan garam dapur.
Bahan kimia yang digunakan yaitu heksan, etanol, $\mathrm{Na}_{2} \mathrm{SO}_{4}, \mathrm{HgO}, \mathrm{H}_{2} \mathrm{SO}_{4}$, akuades, asam borat, BCG-MR, $\mathrm{NaOH}, \mathrm{Na}_{2} \mathrm{~S}_{2} \mathrm{O}_{3}, \mathrm{HCl}$, petroleum eter, $\mathrm{KCl}, \mathrm{NaCH}_{3} \mathrm{COO}$, vitamin C, dan metanol yang diperoleh dari Merck (Darmstad, Jerman), serta DPPH yang diperoleh dari Sigma Chemical Co. (St. Lois, MO).Bahan kimia yang digunakan memiliki spesifikasi pro-analisis.

\section{Pembuatan Bubuk Nasi Beras Hitam}

Pembuatan bubuk nasi beras hitam dilakukan menggunakan metode dari Sutinium dkk. (2008) dengan modifikasi. Beras hitam disortasi, dicuci, kemudian ditanak menggunakan air (beras:air $=2: 3$ (b/v)) selama 20 menit. Selanjutnya dilakukan pengukusan selama 30 menit sehingga diperoleh nasi beras hitam. Nasi beras hitam kemudian dikeringkan menggunakan pengering cabinet pada suhu $50 \mathrm{cC}$ selama 16 jam. Selanjutnya dilakukan penepungan dan pengayakan sehingga diperoleh bubuk nasi beras hitam yang lolos ayakan 80 mesh.

\section{Pembuatan Ekstrak Protein Kedelai Hitam}

Kedelai hitam yang telah dihilangkan kulitnya ditepungkan dan diekstrak menggunakan heksan (heksan:tepung kedelai $=3: 1(\mathrm{v} / \mathrm{b})$ ) selama 2 jam dengan pengulangan sebanyak 3 kali. Adapun penggunaan heksan dalam penelitian ini telah disetujui oleh Komisi Etik Penelitian Kedokteran dan Kesehatan, Fakultas Kedokteran, Universitas Gadjah Mada (Ref: KE/FK/1121/EC). Minyak dan heksan dibuang kemudian tepung kedelai dikeringkan sehingga diperoleh tepung kedelai rendah lemak. Tepung kedelai rendah lemak selanjutnya diekstrak menggunakan etanol $80 \%$ (etanol:tepung $=5: 1(\mathrm{v} / \mathrm{b})$ ) selama $12 \mathrm{jam}$ untuk mengurangi padatan terlarut. Etanol dan padatan terlarut dibuang kemudian tepung dikeringkan menggunakan pengering cabinet suhu $50^{\circ} \mathrm{C}$ selama 16 jam. Setelah itu, dilakukan penepungan dan pengayakan sehingga diperoleh ekstrak protein kedelai hitam yang lolos ayakan 80 mesh.

\section{Analisis Kimia}

Analisis kimia dilakukan pada beras hitam mentah, kedelai hitam mentah, bubuk nasi beras hitam dan ekstrak protein kedelai hitam meliputi penentuan kadar air dengan metode termogravimetri, kadar abu dengan metode pengabuan langsung, kadar protein total dengan metode mikro-Kjeldahl, kadar lemak total dengan metode ekstraksi Soxhlet, dan kadar karbohidrat dengan metode by difference (AOAC, 2005).

\section{Formulasi Minuman Bubuk}

Satu takaran saji minuman bubuk terdiri dari bubuk nasi beras hitam, ekstrak protein kedelai hitam, ektrak antosianin beras hitam, aspartam, dan garam dapur. Semua bahan tersebut dicampur menggunakan metode pencampuran kering. Adapun formulasi minuman 
bubuk dilakukan berdasarkan penentuan energi total dan persentase sumbangan energi yang dibentuk oleh bubuk nasi beras hitam dan ekstrak protein kedelai hitam. Formulasi minuman dapat dilihat pada Tabel 1.

Tabel 1. Formulasi minuman bubuk berbahan dasar beras hitam dan kedelai hitam

\begin{tabular}{lc}
\hline Komponen & Sumbangan energi (\%) \\
\hline Protein & $30 \%$ \\
Karbohidrat & $61 \%$ \\
Lemak & $9 \%$ \\
Energi total & $70 \mathrm{kkal}$ \\
\hline
\end{tabular}

Berdasarkan formula yang disajikan Tabel 1, kemudian ditentukan variasi kadar antosianin pada minuman seperti yang disajikan pada Tabel 2 .

Tabel 2. Variasi kadar antosianin minuman per takaran saji

\begin{tabular}{cccccc}
\hline & \multicolumn{5}{c}{ Formula } \\
\cline { 2 - 6 } & 1 & 2 & 3 & 4 & 5 \\
\hline $\begin{array}{c}\text { Antosianin } \\
\text { (mg/takaran } \\
\text { saji) }\end{array}$ & 0 & 50 & 75 & 100 & 125 \\
\hline
\end{tabular}

\section{Pengujian Sensoris}

Pengujian dilakukan kepada 30 panelis lansia untuk mengetahui tingkat kesukaan terhadap 5 macam formula minuman dengan variasi jumlah penambahan ekstrak antosianin beras hitam. Uji kesukaan dilakukan dengan memberikan skor pada atribut mutu produk meliputi: warna, aroma, rasa, dan keseluruhan dengan skala 1 (sangat tidak menyukai) - 7 (sangat menyukai). Adapun kriteria panelis yang digunakan ialah berusia 55-65 tahun, berjenis kelamin pria dan wanita, dan merupakan panelis tidak terlatih. Sebelum dilakukan pengujian sensoris, minuman bubuk dilarutkan dalam $200 \mathrm{~mL}$ air suhu $\pm 30^{\circ} \mathrm{C}$.

\section{Penyiapan Ekstraksi Sampel}

Sebanyak $1 \mathrm{~g}$ sampel dilarutkan dalam $10 \mathrm{~mL}$ metanol-HCl 1\%. Selanjutnya dilakukan maserasi selama 24 jam pada suhu $4{ }^{\circ} \mathrm{C}$. Sampel disentrifugasi pada kecepatan $3000 \mathrm{rpm}$ selama 15 menit kemudian supernatan diambil untuk analisis antosianin total dan aktivitas penangkapan radikal DPPH.

\section{Analisis Antosianin Total}

Analisis antosianin total dengan metode perbedaan pH dari Giusti dan Wrolstad (Astadi dkk., 2009) dilakukan pada beras hitam dan bubuk nasi beras hitam. Ekstrak sampel sebanyak 0,1 mL dicampur dengan 6,4 $\mathrm{mL}$ larutan buffer $\mathrm{pH} 1$ dan $\mathrm{pH} 4,5$. Kemudian dilakukan pengukuran absorbansi pada $\lambda=513$ dan $700 \mathrm{~nm}$ menggunakan spektrofotometer (Spectronic 8000). Kandungan antosianin dihitung menggunakan Persamaan 1.
Kadar antosianin $(\mathrm{mg} / \mathrm{g}): \frac{A}{\varepsilon x 1} \times \mathrm{BM} \times \mathrm{FP}$

Keterangan:

$$
\begin{array}{ll}
\mathrm{A} & =\text { absorbansi } \\
& \mathrm{A}=\left[\left(\mathrm{A}_{513}-\mathrm{A}_{700}\right) \mathrm{pH} 1-\left(\mathrm{A}_{513}-\mathrm{A}_{700}\right) \mathrm{pH} 4,5\right] \\
\mathrm{BM} & =\text { berat molekul }(449,2) \\
\mathrm{FP} & =\text { faktor pengenceran } \\
\varepsilon & =\text { koefisien ekstingsi molar sianidin-3-glukosida } \\
= & 26.900
\end{array}
$$

\section{Analisis Aktivitas Antioksidan}

Analisis aktivitas antioksidan dilakukan menggunakan metode penangkapan radikal DPPH ( Liyana-Pathirana dan Shahidi, 2007). Sebanyak 0,1 mL ekstrak sampel (kadar $100 \mathrm{ppm}$ ) ditambah $0,5 \mathrm{~mL}$ DPPH 0,5 mM, ditambah $4 \mathrm{~mL}$ metanol, divorteks 1 menit, inkubasi 60 menit, selanjutnya dilakukan peneraan absorbansi pada $516 \mathrm{~nm}$.

$\%$ aktivitas penangkapan radikal DPPH
$=\frac{\text { absorbansi kontrol-absorbansi sampel }}{\text { absorbansi kontrol }} \times 100 \%$

Kontrol mengandung 0,5 mL DPPH dengan $4 \mathrm{~mL}$ metanol. Standar yang digunakan dalam analisis ini adalah vitamin C (kadar 100 ppm).

\section{Analisis Statistik}

Data yang diperoleh diolah menggunakan Statistical Product dan Service Solution (SPSS) 16.0. Pada pengujian sensoris, data diolah menggunakan metodeanalysis of variance (ANOVA) pada tingkat kepercayaan $95 \%$ dengan uji pembedaan menggunakan uji Duncan. Semua data disajikan sebagai rata-rata \pm standar error (S.E.).

\section{HASIL DAN PEMBAHASAN}

\section{Bubuk Nasi Beras Hitam}

Perbandingan komposisi kimia bubuk nasi beras hitam dengan beras hitam mentah disajikan dalam Tabel 3.

Tabel 3. Komposisi kimia beras hitam mentah dan bubuk nasi beras hitam

\begin{tabular}{lcc}
\hline Komposisi & Beras hitam & $\begin{array}{c}\text { Bubuk nasi beras } \\
\text { hitam }\end{array}$ \\
\hline Air (\%wb) & $12,58 \pm 0,03$ & $10,87 \pm 0,26$ \\
Abu (\%db) & $1,98 \pm 0,00$ & $2,15 \pm 0,08$ \\
Protein total (\%db) & $13,07 \pm 0,22$ & $12,77 \pm 0,23$ \\
Lemak total (\%db) & $3,19 \pm 0,02$ & $3,47 \pm 0,11$ \\
Karbohidrat $(b d f)$ & $68,18 \pm 0,23$ & $70,74 \pm 0,31$ \\
Antosianin $(\mathrm{mg} / \mathrm{g})$ & $11,13 \pm 0,33$ & $2,25 \pm 0,43$ \\
\hline
\end{tabular}

Data disajikan sebagai rata-rata \pm S.E.

Bubuk nasi beras hitam merupakan beras hitam yang telah melalui proses penanakan, pengeringan, dan penepungan. Bubuk tersebut digunakan sebagai 
sumber energi dan antosianin dalam formulasi minuman. Berdasarkan Tabel 3, kadar air, protein total, dan antosianin mengalami penurunan. Pada saat penanakan, suhu tinggi menyebabkan perubahan struktur granula pati akibat pecahnya granula pati beras yang tergelatinisasi (Hsu dkk., 2015). Hal tersebut membuat pati yang mengikat air mengalami leaching sehingga air menguap lebih banyak sewaktu proses pengeringan dan terjadi penurunan kadar air. Penurunan kadar protein disebabkan oleh leaching selama proses penanakan. Proses penanakan juga mengakibatkan penurunan kadar antosianin akibat degradasi antosianin yang berdampak pada perubahan strukturnya. Antosianin akan mengalami hidrolisis pada ikatan glikosida sehingga menghasilkan aglikon yang tidak stabil. Selanjutnya, cincin aglikon tersebut akan terbuka dan membentuk struktur kalkon yang tidak berwarna (Patras dkk., 2010). Hou dkk. (2013b) melaporkan bahwa kecepatan degradasi antosianin meningkat seiring meningkatnya suhu dan waktu pemanasan.

Kadar lemak, abu, dan karbohidrat mengalami peningkatan. Peningkatan kadar lemak dapat disebabkan oleh penurunan kadar air. Penurunan kadar air akan memudahkan proses ekstraksi lemak oleh petroleum eter sehingga lemak yang terekstrak menjadi lebih banyak. Pada komponen abu, peningkatan kadar kemungkinan disebabkan oleh penurunan komponen lain seperti protein sehingga menyebabkan proporsi abu bertambah. Akibatnya, persentase kadar abu mengalami kenaikan. Pada komponen karbohidrat, kenaikan dapat disebabkan oleh penurunan jumlah komponen air dan protein. Kadar karbohidrat dihitung secara by difference dengan menghitung selisih persentase bahan total (100\%) dengan komponen air, protein total, lemak, dan abu dalam wet basis. Kadar karbohidrat by difference akan dipengaruhi oleh komponen lain, sehingga apabila terjadi penurunan jumlah komponen air dan protein, akan berkontribusi terhadap kenaikan jumlah karbohidrat, begitu pula sebaliknya.

Adapun rendemen bubuk nasi beras lolos ayakan 80 mesh ialah sebesar 31,5\% (dari $100 \mathrm{~g}$ nasi beras hitam setelah pengeringan). Nasi yang tergelatinisasi saat pemasakan akan mengalami retrogradasi sewaktu dikeringkan. Pada saat retrogradasi, terjadi kristalisasi amilosa pati beras membentuk struktur yang kompak sehingga tekstur nasi kering menjadi lebih keras (Mir dan Don Bosco, 2014). Nasi kering yang keras tersebut menjadi susah untuk digiling sehingga menghasilkan rendemen yang rendah.

\section{Ekstrak Protein Kedelai Hitam}

Berdasarkan hasil analisis kimia terhadap kedelai hitam dan ekstrak protein kedelai hitam, diperoleh data komposisi kimia yang dapat dilihat pada Tabel 4.

Ekstrak protein kedelai hitam merupakan hasil pemisahan tepung kedelai hitam dari komponen minyak dan padatan terlarut berupa monosakarida dan disakarida menggunakan heksan dan etanol. Pemisahan tersebut bertujuan untuk mendapatkan bahan dengan kadar protein yang lebih tinggi dibandingkan dengan tepung kedelai hitam tanpa ekstraksi. Ekstrak protein kedelai hitam digunakan sebagai sumber protein dalam formulasi minuman pada penelitian ini.

Tabel 4. Komposisi kimia kedelai hitam mentah dan ekstrak protein kedelai hitam

\begin{tabular}{lcc}
\hline Komposisi & Kedelai hitam & $\begin{array}{c}\text { Ekstrak protein } \\
\text { kedelai hitam }\end{array}$ \\
\hline Air (\%wb) & $7,89 \pm 0,20$ & $7,14 \pm 0,03$ \\
Abu (\%db) & $4,26 \pm 0,26$ & $5,87 \pm 0,01$ \\
Protein total (\%db) & $37,89 \pm 0,62$ & $51,58 \pm 0,77$ \\
Lemak total (\%db) & $19,93 \pm 0,39$ & $4,47 \pm 0,00$ \\
Karbohidrat ( $b d f)$ & $30,04 \pm 0,50$ & $30,95 \pm 0,78$ \\
\hline
\end{tabular}

Data disajikan sebagai rata-rata \pm S.E.

Berdasakan Tabel 4, kadar protein total mengalami peningkatan setelah ekstraksi. Peningkatan tersebut disebabkan oleh proses ekstraksi minyak menggunakan heksan sehingga terjadi penurunan kadar minyak dan menyebabkan peningkatan proporsi protein pada ektrak protein kedelai hitam (Vishwanathan dkk., 2011).

Proses ekstraksi masih menyisakan kandungan karbohidrat yang cukup tinggi sehingga ekstrak protein kedelai hitam tersebut selain digunakan sebagai sumber protein juga digunakan sebagai sumber karbohidrat pada formulasi minuman. Adapun rendemen ekstrak protein kedelai hitam yang lolos ayakan 80 mesh ialah sebesar 56,60\% (dari $100 \mathrm{~g}$ ekstrak protein kedelai hitam setelah dikeringkan).

\section{Hasil Formulasi Minuman Bubuk}

Setelah diperoleh data hasil analisis kimia bubuk nasi beras hitam dan ekstrak protein kedelai hitam, dilakukan formulasi menurut ketentuan energi total dan sumbangan energi pada Tabel 1. Penentuan energi total tersebut mengacu pada produk minuman susu untuk lansia yang telah beredar di pasaran Indonesia yaitu sekitar 70-140 kkal/takaran saji. Sedangkan persentase sumbangan energi diperoleh dari hasil orientasi untuk mendapatkan formula yang paling mendekati sifat fisik dan sensoris minuman untuk lansia yang sudah beredar di pasaran.

Dengan melihat komposisi kimia bubuk nasi beras hitam (Tabel 3) dan ekstrak protein kedelai hitam (Tabel 4), dilakukan perhitungan sumbangan energi komponen protein, karbohidrat, dan lemak untuk menghasilkan energi total sebesar 70 kkal/takaran saji minuman bubuk serta perhitungan kebutuhan jumlah komponen bubuk nasi beras hitam dan ekstrak protein kedelai hitam. Setiap gram protein beras memberikan sumbangan 3,82 kkal, setiap gram karbohidrat beras diketahui memberikan sumbangan 4,26 kkal, sedangkan setiap gram lemak beras memberikan 8,37 kkal. Setiap gram residu ekstrak kedelai memberikan sumbangan 3,47 kkal, setiap gram karbohidrat residu ekstrak kedelai memberikan sumbangan 4,07 kkal, dan 
setiap gram lemak residu ekstrak kedelai memberikan sumbangan 8,37 kkal (Mahmud dkk., 2009).

Hasil perhitungan sumbangan energi dari komponen protein, karbohidrat, dan lemak minuman disajikan pada Tabel 5.

Tabel 5. Sumbangan energi bubuk minuman per takaran saji

\begin{tabular}{lcc}
\hline Komponen* & Persentase (\%) & Kalori (kkal) \\
\hline Protein & 30 & 21 \\
Karbohidrat & 60,84 & 42,6 \\
Lemak & 9,16 & 6,4 \\
Total & 100 & 70 \\
\hline *basis perhingan
\end{tabular}

*basis perhitungan adalah total energi yang dihasilkan oleh bubuk minuman per takaran saji (70 kkal)

Hasil perhitungan kebutuhan jumlah komponen bubuk nasi beras hitam dan ekstrak protein kedelai hitam yang dibutuhkan untuk formulasi disajikan pada Tabel 6. Pada tabel tersebut juga disajikan jumlah aspartam dan garam dapur yang ditambahkan per takaran saji.

Tabel 6. Jumlah komponen bahan per takaran saji

\begin{tabular}{lc}
\hline Bahan & Berat $(\mathrm{g})$ \\
\hline Bubuk nasi beras hitam & 10,76 \\
Ekstrak protein kedelai hitam & 8,80 \\
Aspartam & 0,05 \\
Garam dapur & 0,1 \\
\hline
\end{tabular}

Untuk mengetahui pengaruh kadar ekstrak antosianin beras hitam terhadap tingkat kesukaan lansia, dilakukan penambahan ekstrak antosianin menggunakan 5 variasi kadar ekstrak sehingga didapatkan 5 formula minuman dengan variasi kadar antosianin yang disajikan pada Tabel 7. Adapun ekstrak antosianin beras hitam yang digunakan mengandung antosianin sebesar $200,39 \pm 0,00 \mathrm{mg} / \mathrm{g}$.

Tabel 7. Jumlah ekstrak antosianin per takaran saji minuman

\begin{tabular}{lcc}
\hline Minuman & $\begin{array}{c}\text { Kandungan } \\
\text { antosianin } \\
\text { (mg/takaran saji) }\end{array}$ & $\begin{array}{c}\text { Ekstrak antosianin } \\
\text { beras hitam yang } \\
\text { ditambahkan }(\mathrm{g})\end{array}$ \\
\hline Formula 1 & 24,21 & 0 \\
Formula 2 & 50 & 0,13 \\
Formula 3 & 75 & 0,25 \\
Formula 4 & 100 & 0,38 \\
Formula 5 & 125 & 0,50 \\
\hline
\end{tabular}

\section{Sifat Sensoris Minuman}

Hasil analisis tingkat kesukaan lansia terhadap atribut sensoris (warna, aroma, rasa, dan keseluruhan) dari 5 variasi formula minuman dapat dilihat pada Tabel 8.

Analisis statistik terhadap hasil pengujian menunjukkan bahwa tidak ada perbedaan nyata pada tingkat kesukaan panelis terhadap warna, aroma, rasa, dan keseluruhan dari 5 formula minuman. Untuk selanjutnya, dipilih formula minuman dengan kandungan antosianin $100 \mathrm{mg} /$ takaran saji untuk pengujian aktivitas antioksidan. Pemilihan tersebut dilakukan berdasarkan pada Acceptable daily Intake (ADI) antosianin untuk manusia yaitu sebesar 2,5 $\mathrm{mg} / \mathrm{kg}$ berat badan per hari (Clifford 2000 dalam He \& Giusti (2010)). Apabila seorang lansia mempunyai berat badan $60 \mathrm{~kg}$, maka perkiraan ADI antosianin sebesar 150 mg/hari. Konsumsi minuman dengan kadar antosianin $100 \mathrm{mg} /$ takaran saji diharapkan dapat melengkapi kebutuhan antosianin dari makanan yang lain yang dikonsumsi selain minuman ini.

\section{Aktivitas Antioksidan Minuman Bubuk}

Aktivitas antioksidan minuman bubuk berbahan dasar beras hitam dinyatakan dalam persen kemampuan penangkapan radikal DPPH yang disajikan pada Gambar 1.

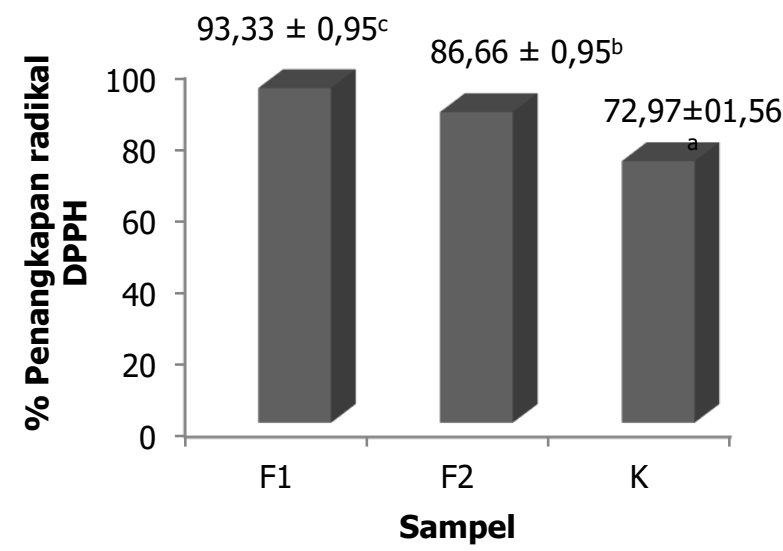

Gambar 1. Grafik persen (\%) penangkapan radikal DPPH F1 = minuman beras dengan penambahan ekstrak antosianin (kadar antosianin $100 \mathrm{mg} /$ takaran saji), F2 = Minuman beras tanpa penambahan ekstrak antosianin (kadar antosianin 24,21 mg/takaran saji), dan $\mathrm{K}=$ Kontrol (vitamin C 100 ppm). Data disajikan sebagai rata-rata \pm S.E. Huruf yang berbeda pada masing-masing histogram menunjukkan ada perbedaan nyata $(p<0,05)$

Berdasarkan grafik tersebut, minuman bubuk dengan penambahan ekstrak antosianin memiliki

Tabel 8. Tingkat kesukaan lansia terhadap minuman

\begin{tabular}{lccccc}
\hline & & & Formula minuman & & \\
& $24,21 \mathrm{mg}$ & $50 \mathrm{mg}$ & $75 \mathrm{mg}$ & $100 \mathrm{mg}$ & $125 \mathrm{mg}$ \\
\hline Warna & $4,07 \pm 0,18^{\mathrm{a}}$ & $4,3 \pm 0,17^{\mathrm{ab}}$ & $4,67 \pm 0,19^{\mathrm{a}}$ & $4,43 \pm 0,18^{\mathrm{ab}}$ & $4,13 \pm 0,20^{\mathrm{ab}}$ \\
Aroma & $4,8 \pm 0,16^{\mathrm{a}}$ & $4,8 \pm 0,16^{\mathrm{a}}$ & $4,8 \pm 0,16^{\mathrm{a}}$ & $4,8 \pm 0,16^{\mathrm{a}}$ & $4,8 \pm 0,16^{\mathrm{a}}$ \\
Rasa & $5,03 \pm 0,19^{\mathrm{a}}$ & $5,03 \pm 0,19^{\mathrm{a}}$ & $5,03 \pm 0,19^{\mathrm{a}}$ & $5,03 \pm 0,19^{\mathrm{a}}$ & $5,03 \pm 0,19^{\mathrm{a}}$ \\
Keseluruhan & $4,63 \pm 0,11^{\mathrm{a}}$ & $4,73 \pm 0,10^{\mathrm{a}}$ & $4,87 \pm 0,12^{\mathrm{a}}$ & $4,8 \pm 0,12^{\mathrm{a}}$ & $4,7 \pm 0,14^{\mathrm{a}}$ \\
\hline
\end{tabular}

Keterangan: 1 = sangat tidak menyukai, $2=$ tidak menyukai, $3=$ agak tidak menyukai, $4=$ netral, $5=$ agak menyukai, $6=$ menyukai, $7=$ sangat menyukai, Data disajikan sebagai rata-rata S.E. $(n=30)$. Huruf yang sama pada baris yang sama menunjukkan tidak beda nyata $(p<$ $0,05)$ 
aktivitas antioksidan yang secara signifikan lebih tinggi daripada kontrol vitamin $C(p=0,002)$, ditandai dengan lebih tingginya persen penangkapan radikal DPPH. Makin tinggi kadar antosianin, akan menyebabkan peningkatan kemampuan penangkapan terhadap radikal $\mathrm{DPPH}$, sehingga aktivitas antioksidannya juga makin tinggi (Jakobek dkk., 2007).

\section{Sumbangan Nilai Gizi Minuman terhadap Angka Kecukupan Gizi Untuk Lansia}

Berdasarkan data persentase sumbangan energi minuman pada Tabel 5, dilakukan perhitungan sumbangan nilai gizi minuman terhadap angka kecukupan gizi untuk lansia yang dapat dilihat pada Tabel 9.

Tabel 9. Sumbangan nilai gizi terhadap angka kecukupan gizi untuk lansia

\begin{tabular}{lccc}
\hline Zat gizi & $\begin{array}{c}\text { Jumlah per } \\
\text { sajian }\end{array}$ & Kalori & $\%$ AKG* \\
\hline Energi total & & $70 \mathrm{kkal}$ & $3,68-4,52$ \\
Protein & $10,34 \mathrm{~g}$ & $42,6 \mathrm{kkal}$ & $3,34-4,10$ \\
Karbohidrat & $5,91 \mathrm{~g}$ & $21 \mathrm{kkal}$ & $9,53-10,55$ \\
Lemak & $0,77 \mathrm{~g}$ & $6,4 \mathrm{kkal}$ & $1,45-1,79$ \\
Air & $200 \mathrm{~mL}$ & - & $10,53-12,5$ \\
\hline *berdasarkan kebutuhan energi total, protein, karbohidrat, dan lemak \\
pada lansia pria dan wanita usia 65-80 tahun per hari menurut Angka \\
Kecukupan Gizi bagi orang Indonesia (Kementerian Kesehatan, 2013).
\end{tabular}

Berdasarkan Tabel 9, dapat diketahui bahwa minuman mampu memenuhi 3,68-4,52\% kebutuhan energi total, 3,34-4,10\% kebutuhan protein, 9,53$10,55 \%$ kebutuhan karbohidrat, dan 1,45-1,79\% kebutuhan lemak pada lansia untuk satu hari. Selain itu, penyajian minuman dengan melarutkan bubuk ke dalam $200 \mathrm{~mL}$ air juga membantu mencukupi 10,53-12,5\% kebutuhan cairan tubuh per hari. Data sumbangan nilai gizi tersebut memberikan gambaran bahwa minuman berbahan dasar beras hitam dapat dijadikan salah satu alternatif minuman yang dapat dikonsumsi untuk membantu melengkapi kebutuhan gizi lansia, khususnya lansia penderita DM tipe 2 .

\section{KESIMPULAN}

Telah didapatkan formula minuman untuk lansia penyandang DM tipe 2 yang terdiri atas bubuk nasi beras hitam $(10,76 \mathrm{~g})$, residu ekstrak kedelai hitam $(8,8$ g), ekstrakantosianin beras hitam (0,38 g), aspartam (50 $\mathrm{mg})$, dan garam dapur $(0,1 \mathrm{~g})$ per takaran saji $(19,91$ $\mathrm{g} / 200 \mathrm{~mL}$ ). Formula tersebut merupakan formula yang paling disukai lansia dengan kandungan antosianin sebesar 100 mg/takaran saji. Minuman bubuk mempunyai aktivitas antioksidan (\% penangkapan radikal DPPH) sebesar 93,33 $\pm 0,95 \%$. Setiap takaran saji minuman mampu melengkapi 3,68-4,52\% kebutuhan energi total, 3,34-4,10\% kebutuhan protein, 9,53-10,55\% kebutuhan karbohidrat, 1,45-1,79\% kebutuhan lemak, dan 10,53-12,5\% kebutuhan cairan tubuh lansia per hari.

\section{UCAPAN TERIMA KASIH}

Penulis mengucapkan terima kasih kepada Ditjen Dikti yang telah memberikan bantuan dana untuk penelitian ini melalui Beasiswa Unggulan Calon Dosen tahun 2012.

\section{DAFTAR PUSTAKA}

AOAC. (1970). Official Methods of Analysis. Association of Official Analytical Chemist (AOAC). Washington DC, USA: Association of Official Analytical Chemist.

Brand-Williams, W., Cuvelier, M. E., \& Berset, C. (1995). Use of a free radical method to evaluate antioxidant activity. Food Science and Technology, 28, 25-30.

Chen, X. Q., Nagao, N., Itani, T., \& Irifune, K. (2012). Antioxidative analysis, and identification and quantification of anthocyanin pigments in different coloured rice. Food Chemistry, 135, 2783-2788. http://doi.org/10.1016/j.foodchem.2012.06.098.

Guo, H., Ling, W., Wang, Q., Liu, C., Hu, Y., Xia, M., ... Xia, X. (2007). Effect of Anthocyanin-Rich Extract from Black Rice ( Oryza sativa L . indica ) on Hyperlipidemia and Insulin Resistance in Fructose-Fed Rats, 62, 1-6. http://doi.org/10.1007/s11130-006-0031-7.

He, J., \& Giusti, M. M. (2010). Anthocyanins: natural colorants with healthpromoting properties. The Annual Review of Food Science and Technology, 1, 163-187.

Hou, F., Zhang, R., Zhang, M., Su, D., Wei, Z., Deng, Y., ... Tang, X. (2013). Hepatoprotective and antioxidant activity of anthocyanins in black rice bran on carbon tetrachloride-induced liver injury in mice. Journal of Functional Foods, 5, 1705-1713. http://doi.org/10.1016/j.jff.2013.07.015.

Hou, Z., Qin, P., Zhang, Y., Cui, S., \& Ren, G. (2013). Identi fi cation of anthocyanins isolated from black rice ( Oryza sativa L .) and their degradation kinetics. FRIN, 50, 691697. http://doi.org/10.1016/j.foodres.2011.07.037.

Jakobek, L., Seruga, M., Medvidovic-Kosanovic, M., \& Novak, I. (2007). Anthocyanin content and antioxidant activity of various red fruit juice. Deutsche LebensmiltelRundschau, 103, 58-64.

Jang, E. H., Ko, J. H., Ahn, C. W., Lee, H. H., Shin, J. K., Chang, S. J., ... Kang, J. H. (2010). In vivo and in vitro application of black soybean peptides in the amelioration of endoplasmic reticulum stress and improvement of insulin resistance. Life Sciences, 86, 267-274. http://doi.org/10.1016/j.Ifs.2009.12.012.

Kesehatan, K. (2013). Angka Kecukupan Gizi yang Dianjurkan bagi Bangsa Indonesia. http://gizi.depkes.go.id/download/Kebijakan\%20Gizi/Tab el\%20AKG.pdf.

Kumawat, M., Kumar, T., Singh, I., \& Singh, N. (2012). Decrease in antioxidant status of plasma and erythrocytes from geriatric population, 33, 303-308. http://doi.org/10.3233/DMA-2012-00938.

Mahmud, M. K., Hermana, Zulfianto, N. A., Rozanna, R., Apriyanto, Ngadiarti, I., ... Tinexcelly. (2009). Tabel Komposisi Pangan Indonesia (TKPI). Jakarta: Elex Media Komputindo.

Navaratnarajah, A., \& Jackson, S. H. D. (2013). The physiology of ageing. Medicine, 41(1), 5-8. http://doi.org/10.1016/j.mpmed.2012.10.009.

Patras, A., Brunton, N. P., Donnell, C. O., \& Tiwari, B. K. 
(2010). Effect of thermal processing on anthocyanin stability in foods; mechanisms and kinetics of degradation. Trends in Food Science \& Technology, 21(1), 3-11. http://doi.org/10.1016/j.tifs.2009.07.004.

Pramitasari, R., Astuti, M., \& Naruki, S. (n.d.). Evaluasi sensoris, nilai gizi, dan sifat fisik minuman berbasis beras (Oryza sativa L.) untuk orang lanjut usia. In Prosiding Seminar Nasional Konsumsi Pangan Sehat dengan Gizi Seimbang Menuju Tubuh Sehat Bebas Penyakit (pp. 199212). Yogyakarta.

Sutinium, D., \& Haruthaithasan, V. (2008). Development of Instant Nutritious Beverage from Germinated Jasmine Brown Rice for Elderly Consumers, 98, 88-98.

Vishwanathan, K. H., Singh, V., \& Subramanian, R. (2011). Influence of particle size on protein extractability from soybean and okara. Journal of Food Engineering, 102(3), 240-246. http://doi.org/10.1016/j.jfoodeng.2010.08.026.

Wrolstad, R. E., Durst, W., \& Lee, J. (2005). Tracking color and pigment changes in anthocyanin products, 16, 423-428. http://doi.org/10.1016/j.tifs.2005.03.019. 